\title{
Utilization of Forgoing Coastal Rice Fallow Lands of Bangladesh with Zero Tillage Potato Cultivation using Different Rates of Residues
}

\author{
Mustafa Kamal Shahadat ${ }^{1}$, Mohammad Harunor Rashid ${ }^{1}$, Mohammad Akkas Ali 2,* and \\ Mohammed Mainuddin ${ }^{3}$ \\ 1 Bangladesh Agricultural Research Institute, On-Farm Research Division, Daulatpur, Khulna 9202, \\ Bangladesh; mustafa.shahadat@gmail.com (M.K.S.); md_harunor_rashid@yahoo.com (M.H.R.) \\ 2 Bangladesh Agricultural Research Institute, On-Farm Research Division, Joydebpur, Gazipur 1701, \\ Bangladesh \\ 3 Black Mountain Laboratories, GPO Box 1700, Canberra ACT 2601, Australia; \\ Mohammed.Mainuddin@csiro.au \\ * Correspondence: akkasbari@gmail.com \\ + Presented at the third International Tropical Agriculture Conference (TROPAG 2019), Brisbane, Australia, \\ 11-13 November 2019.
}

Published: 2 February 2020

\begin{abstract}
An experiment was conducted in south-western coastal saline area of Khulna district of Bangladesh $\left(22^{\circ} 35^{\prime} 53.463^{\prime \prime} \mathrm{N}\right.$ latitude and $89^{\circ} 27^{\prime} 42.617^{\prime \prime} \mathrm{E}$ longitude) during the period from December 2018 to March 2019. The experiment was laid out in two factor Randomized Complete Block (RCB) design with three replications. Factor A included two potato varieties ( $\mathrm{V}_{1}=$ BARI Alu72 and $\mathrm{V}_{2}=\mathrm{BARI}$ Alu-73) and factor $\mathrm{B}$ consisted with three rates of rice straw mulch viz. $\mathrm{M}_{1}=4$ ton $\mathrm{ha}^{-1}, \mathrm{M}_{2}=7$ ton ha- ${ }^{-1}$ and $\mathrm{M}_{3}=10$ ton ha- $\mathrm{h}^{-1}$. Average thickness of mulch treatments were $11 \mathrm{~cm}, 13 \mathrm{~cm}$ and $15 \mathrm{~cm}$, respectively. Mulch rate had significant effect on different soil and crop parameters, however there was no significant effect observed in variety and variety vs mulch rate. At harvest, highest plant height $(50.7 \mathrm{~cm})$, stem dry weight $\left(1.33 \mathrm{~g} \mathrm{plant}^{-1}\right)$ and leaf dry weight $\left(7.29 \mathrm{~g} \mathrm{plant}^{-1}\right)$ were recorded from $\mathrm{M}_{3}$ treatment. In case of yield components and yield, $\mathrm{M}_{3}$ treatment gave highest value for number of tuber per plant (7.11), individual tuber weight (59.38 g), tuber yield $\left(15.62 \mathrm{t} \mathrm{ha}^{-1}\right)$, haulm yield $\left(2.26 \mathrm{t} \mathrm{ha}^{-1}\right)$. Significantly highest moisture was conserved by $\mathrm{M}_{3}$ treatment $(27.13 \%)$ at harvest as well effectively controlled salinity $\left(E_{e}\right.$ ) increase (only $1.25 \%$ increase than initial). So, it is observed that rice straw @ $10 \mathrm{t} \mathrm{ha}^{-1}$ is most suitable for zero tillage potato cultivation in the coastal area of Bangladesh.
\end{abstract}

Keywords: potato; zero tillage; mulch rate; salinity; dry matter; tuber yield

Funding: This research was jointly funded by Australian Centre for International Agricultural Research (ACIAR) (LWR/2014/073) and Krishi Gobeshona Foundation (KGF) (ICP I), Bangladesh.

Acknowledgments: We are thankful to Richard Bell, Murdoch University, Australia for his valuable suggestions and encouragement.

Conflicts of Interest: The author declares no conflict of interest. 